FOLIA POMERANAE UNIVERSITATIS TECHNOLOGIAE STETINENSIS

Folia Pomer. Univ. Technol. Stetin., Oeconomica 2017, 335(87)2, 205-212

Edward NOWAK

\title{
BADANIA EMPIRYCZNE W PRACACH LICENCJACKICH I MAGISTERSKICH Z ZAKRESU RACHUNKOWOŚCI
}

\section{EMPIRICAL RESEARCH IN BACHELOR'S AND MASTER'S THESES ON ACCOUNTING}

Katedra Rachunku Kosztów, Rachunkowości Zarządczej i Controllingu, Uniwersytet Ekonomiczny we Wrocławiu, ul. Komandorska 118/120, 53-345 Wrocław, e-mail: edward.nowak@ue.wroc.pl

\begin{abstract}
Summary. The paper refers to the issue of conducting empirical research in Bachelor's and Master's theses. An analysis of financial accounting data is conducted by students mainly in theses on Economic Analysis, especially Financial Analysis. Empirical data used in theses on Accounting can have the form of dynamic data, cross-sectional data or dynamic - crosssectional data. The type and scope of applied empirical data depends mainly on the objective of the research. It is important to apply a suitable procedure and data processing method. There occur significant differences between the research scope and empirical data analysis methods in Bachelor's and Master's theses. Empirical research cunducted in Master's theses is considerably more advanced than those conducted in Bachelor's theses.
\end{abstract}

Słowa kluczowe: prace dyplomowe, rachunkowość, analiza danych, badania empiryczne, metody ilościowe.

Key words: diploma theses, accounting, data analysis, empirical research, quantitative methods.

\section{WSTĘP}

Elementem procesu dydaktycznego na poziomie studiów I i II stopnia jest w większości szkół wyższych napisanie przez studentów pracy dyplomowej - licencjackiej i magisterskiej. Dotyczy to także prac z zakresu rachunkowości, które są realizowane na specjalnościach z zakresu rachunkowości lub pokrewnych. Jest to szczególnie ważne na tych specjalnościach, gdyż rachunkowość jest dyscypliną praktyczną, ma charakter podmiotowy i opisuje kształtowanie się zjawisk ekonomicznych w konkretnych jednostkach gospodarczych oraz instytucjach.

Prace dyplomowe z zakresu rachunkowości, tak jak z każdej innej dyscypliny ekonomicznej, mogą mieć charakter opisowy lub badawczy. Prace licencjackie lub magisterskie o charakterze badawczym obejmują badania empiryczne w konkretnych jednostkach. Realizowane przez studentów prace z rachunkowości o charakterze badawczym służą poznawaniu rzeczywistości gospodarczej. Ważne jest to, żeby na podstawie przeprowadzanych badań empirycznych student wyciągał odpowiednie wnioski. Ich poprawność zależy w dużym stopniu od zastosowania właściwych metod analizy danych (Nadolna 2009). W badaniach empirycznych dotyczących zjawisk ekonomicznych szczególnie przydatne są metody statystyczne. Umożliwiają one bowiem gromadzenie, przetwarzanie i analizę licznych zbiorów danych liczbowych opisujących 
kształtowanie się badanych zjawisk. Ważne jest także to, że dostarczają one obiektywnych informacji ekonomicznych, które są rezultatem przetworzenia pierwotnych danych finansowo-księgowych (Nowak 2001).

Głównym celem niniejszego artykułu jest ukazanie specyfiki i walorów prac licencjackich i magisterskich z rachunkowości, które powstały na podstawie przeprowadzonych badań empirycznych dotyczących kształtowania się pewnych zjawisk i procesów gospodarczych w wybranych jednostkach o określonym profilu działalności. Zasadnicza teza artykułu zawiera się w stwierdzeniu, że badania empiryczne prowadzone przez studentów w ramach prac dyplomowych kształtują ważne umiejętności analityczne.

\section{MATERIAt I METODY}

Badaniem objęto przede wszystkim materiały własne autora artykułu, dotyczące tematów prac licencjackich i magisterskich podejmowanych w ostatnich 15 latach pod jego kierunkiem. Były to głównie prace pisane w Katedrze Rachunku Kosztów, Rachunkowości Zarządczej i Controllingu na Wydziale Zarządzania, Informatyki i Finansów Uniwersytetu Ekonomicznego we Wrocławiu, a także w Zakładzie Finansów, Bankowości i Rachunkowości na Wydziale Zarządzania Politechniki Rzeszowskiej. Sformułowane wnioski wynikają zatem z własnych obserwacji i doświadczeń.

W artykule wykorzystano także literaturę z zakresu rachunkowości, analizy ekonomicznej i statystycznej. Szczególną uwagę zwrócono na pozycje dotyczące metod badawczych stosowanych w badaniach empirycznych przeprowadzanych w różnego rodzaju jednostkach: przedsiębiorstwach, instytucjach finansowych, jednostkach sektora publicznego i jednostkach nieprowadzących działalności gospodarczej. Poświęcone tym zagadnieniom wybrane pozycje literatury poddano krytycznej analizie, na podstawie której sformułowano wnioski.

W opracowaniu artykułu zastosowano, przede wszystkim, takie metody badawcze, jak analiza materiałów źródłowych oraz metody dedukcji i indukcji.

\section{PROBLEMATYKA PRAC DYPLOMOWYCH Z RACHUNKOWOŚCI OBEJMUJĄCYCH BADANIA EMPIRYCZNE}

Badania empiryczne mogą być przeprowadzane zarówno w ramach prac licencjackich, jak i magisterskich z zakresu rachunkowości. Najczęściej tematy takich prac dotyczą analizy finansowej lub szerzej: analizy ekonomicznej. Takie analizy są przeprowadzane w różnego rodzaju jednostkach: przedsiębiorstwach, instytucjach finansowych, jednostkach sektora finansów publicznych czy jednostkach nieprowadzących działalności gospodarczej. W każdej wymienionej jednostce należy bowiem analizować i oceniać kształtowanie się różnych zjawisk i procesów gospodarczych odzwierciedlających ich działalność. Niekiedy badania empiryczne o charakterze analizy ex post są wykorzystywane do prognozowania gospodarczego w jednostkach, tzn. do badań ex ante.

Prace dyplomowe z rachunkowości są często pisane w Katedrze Rachunku Kosztów, Rachunkowości Zarządczej i Controllingu na Wydziale Zarządzania, Informatyki i Finansów w Uniwersytecie Ekonomicznym we Wrocławiu, ponieważ obszary rachunkowości wyszczególnione 
w nazwie Katedry obejmują przygotowanie i wykorzystanie informacji z rachunkowości w zarządzaniu określonymi jednostkami. Chodzi przede wszystkim o wykorzystanie wyników badania empirycznego do oceny działalności różnych jednostek oraz do podejmowania decyzji gospodarczych. Analiza ekonomiczna, w szczególności analiza finansowa, stanowi bowiem ważne narządzie zarządzania w przedsiębiorstwach i instytucjach. Może ona mieć nie tylko charakter retro-, ale także prospektywny.

Wybrane tematy prac licencjackich i magisterskich pisanych w Katedrze Rachunku Kosztów, Rachunkowości Zarządczej i Controllingu, na potrzeby których są przeprowadzane badania empiryczne, zostały przedstawione są w tab. 1.

Tabela 1. Przykłady tematów prac dyplomowych z rachunkowości o charakterze badawczym

\begin{tabular}{|r|l|}
\hline \multicolumn{1}{|c|}{ Temat pracy } \\
\hline 1 & Analiza kosztów działalności przedsiębiorstwa \\
2 & Analiza przychodów, kosztów i wyników finansowych przedsiębiorstwa \\
3 & Ocena sytuacji majątkowo-finansowej na podstawie bilansu \\
4 & Analiza rachunku zysków i strat w ocenie rentowności \\
5 & Wskaźnikowa analiza sytuacji finansowej przedsiębiorstwa \\
6 & Analiza sprawozdania finansowego w ocenie sytuacji finansowej \\
7 & Analiza wykonania budżetu jednostki samorządu terytorialnego \\
8 & Analiza dochodów i wydatków gminy \\
9 & Porównawcza analiza sytuacji finansowej wybranych spółek z branży \\
10 & Analiza obciążeń podatkowych przedsiębiorstwa \\
\hline \multicolumn{2}{|}{} \\
\hline 1 & Analiza kosztów w ocenie efektywności działalności przedsiębiorstwa \\
2 & Ocena rentowności działalności przedsiębiorstwa \\
3 & Ocena efektywności przedsięwzięcia inwestycyjnego \\
4 & Ocena sytuacji finansowej w badaniu zdolności kredytowej jednostki \\
5 & Retrospektywna i prospektywna analiza sytuacji finansowej jednostki \\
6 & Analiza budżetu kosztów oraz jego realizacji w przedsiębiorstwie \\
7 & Analiza finansowa w badaniu zdolności do kontynuowania działalności \\
8 & Analiza i dobór źródeł finansowania działalności jednostki \\
9 & Wpływ obciążeń podatkowych na wyniki jednostki gospodarczej \\
10 & Ocena stanu i efektywności wykorzystania środków trwałych \\
\hline
\end{tabular}

Źródło: opracowano na podstawie wykazu tematów prac realizowanych w Katedrze Rachunku Kosztów, Rachunkowości Zarządczej i Controllingu Uniwersytetu Ekonomicznego we Wrocławiu.

W tabeli zostały zaprezentowane tylko przykładowe tematy prac dyplomowych z rachunkowości o charakterze badawczym. Niektóre tematy są wybierane przez studentów często, np. te poświęcone analizie finansowej czy analizie kosztów. Przedstawiona w tab. 1 lista tematów nie jest kompletna. Ponadto przytoczone tematy mogą być realizowane na przykładzie jednostek o odmiennym charakterze działalności.

Porównawcza analiza tematów przedstawionych w tab. 1 wskazuje, że tematy podejmowane w pracach magisterskich są trudniejsze niż w pracach licencjackich. Prace licencjackie o charakterze badawczym są poświęcone, przede wszystkim, analizie różnych zjawisk i procesów gospodarczych, z elementami oceny ich kształtowania się w wybranych jednostkach. Takie oceny są natomiast obligatoryjne w pracach magisterskich, które powinny też umożliwić formułowanie wniosków dotyczących wpływu analizowanych zjawisk i procesów na kształtowanie się pewnych kategorii ekonomicznych lub/i podejmowanie odpowiednich decyzji gospodarczych. 


\section{ZAKRES BADANIA I RODZAJE DANYCH EMPIRYCZNYCH}

Badania empiryczne, przeprowadzane na podstawie danych finansowo-księgowych, mogą mieć różny zakres. Zależy on przede wszystkim od celu badania, którym najczęściej jest ocena kształtowania sie określonych zdarzeń gospodarczych lub zjawisk i procesów ekonomicznych. Owe zdarzenia, zjawiska i procesy poddane badaniu empirycznemu są przedstawiane z wykorzystaniem różnych mierników i wskaźników, których wartości uzyskuje się w rezultacie pomiaru w systemie rachunkowości.

Mierniki stosowane $\mathrm{w}$ rachunkowości są liczbowym wyrażeniem określonych zjawisk i procesów gospodarczych poddanych analizie. Są one wielkościami, które mogą przybierać odmienne wartości w różnych warunkach i informują o stanie obserwowanych zjawisk. Liczbowe natomiast realizacje mierników stanowią dane empiryczne, które po odpowiednim przetworzeniu tworzą informacje ekonomiczne. Kluczowym zadaniem w badaniach empirycznych jest określenie zestawu mierników, które charakteryzują zjawiska i procesy podlegające analizie. Gromadzenie odpowiednich danych empirycznych jest natomiast czynnością bardziej techniczną niż merytoryczną.

Dane empiryczne, będące wynikiem pomiaru zjawisk i procesów ekonomicznych, mogą dotyczyć różnych jednostek (obiektów) badania. Biorąc pod uwagę to kryterium, można wyróżnić 3 rodzaje danych (Suchecka 2011):

1) dane dynamiczne, które ukazują kształtowanie się badanych zjawisk w czasie w wybranej jednostce gospodarczej (organizacyjnej); można je podzielić na:

a) dane przedstawiające stany zjawiska w ustalonych momentach w pewnym przedziale czasu; dane takie dotyczą zasobów;

b) dane przedstawiające wartości zjawiska w kolejnych okresach ustalonego przedziału czasu; dane takie dotyczą zjawisk mających postać strumieni;

2) dane przekrojowe, które są uporządkowanymi wartościami zjawiska w zbiorze jednostek gospodarczych (organizacyjnych) w ustalonej jednostce czasu (okresie lub momencie);

3) dane dynamiczno-przekrojowe, z którymi ma się do czynienia wówczas, gdy dysponuje się wynikami pomiarów zjawiska w kolejnych jednostkach czasu pewnego przedziału czasowego w zbiorze jednostek gospodarczych (organizacyjnych).

Wyróżnienie badań dynamicznego, przekrojowego i dynamiczno-przekrojowego ma znaczenie dla określenia zakresu danych empirycznych, które należy zgromadzić na potrzeby badania. Ponadto jest ono istotne ze względu na wybór odpowiedniego podejścia badawczego i zastosowanie właściwych metod obróbki danych empirycznych.

Badanie empiryczne jest wieloetapowym postępowaniem badawczym stanowiącym proces przetwarzania danych. Proces ten obejmuje ciąg powiązanych ze sobą czynności, które powinny być realizowane w odpowiedniej kolejności. Na proces przetwarzania danych empirycznych składają się następujące etapy (Nowak 2016):

- wstępna analiza badanego systemu gospodarczego;

- wskazanie podstawowych celów badania (głównego i szczegółowych);

- ustalenie przedmiotowego, podmiotowego i czasowego zakresu badania;

- określenie układu danych empirycznych i ich zgromadzenie;

- wstępną analizę danych empirycznych oraz ocenę ich jakości; 
- określenie procedury przetwarzania danych oraz wybór odpowiednich metod ich analizy;

- przeprowadzenie odpowiednich obliczeń, zazwyczaj z zastosowaniem metod ilościowych;

- interpretację osiągniętych wyników oraz sformułowanie wniosków i ocen analizy.

Przedstawiona procedura stanowi uporządkowane podejście badawcze realizowane za pomocą odpowiednich metod, które powinny być dostosowane do charakteru badania i jego celów. Poprawność ich doboru i zastosowania przesądza o praktycznej użyteczności otrzymanych wyników. Należy przy tym pamiętać, że wyniki badań empirycznych są, przede wszystkim, odzwierciedleniem stanów zjawisk ekonomicznych w przeszłości w okresie objętym analizą. Tylko w pewnych sytuacjach, przy spełnieniu określonych warunków, można je wykorzystać do wnioskowania o przyszłym kształtowaniu się badanych zjawisk (Nowak 2016). Ważne jest to, że dzięki przetworzeniu pochodzących z rachunkowości danych empirycznych zwiększa się możliwości interpretacji uzyskanych wyników (Hendriksen i Breda 2002).

\section{WNIOSKI}

Jednym z 3 podstawowych efektów kształcenia na kierunkach ekonomicznych jest wykształcenie określonych umiejętności. Jedna z takich umiejętności studentów z zakresu rachunkowości dotyczy przeprowadzania badania empirycznego oraz formułowania na jego podstawie odpowiednich ocen i wniosków. Ten cel kształcenia jest osiągany, przede wszystkim, przez pisanie prac dyplomowych o charakterze teoretyczno-badawczym. Z rozważań przeprowadzonych wyżej wynika, że ich zakres oraz stopień złożoności są inne w przypadku prac licencjackich, a inne w przypadku prac magisterskich. Porównanie tych prac dyplomowych ze względu na stopień zaawansowania badań empirycznych przedstawia tab. 2 .

Tabela 2. Różnice zakresu badań empirycznych w pracach licencjackich i magisterskich

\begin{tabular}{|l|l|l|}
\hline \multicolumn{1}{|c|}{ Cechy badań } & \multicolumn{1}{|c|}{ Prace licencjackie } & \multicolumn{1}{c|}{ Prace magisterskie } \\
\hline Podmiot badań & zazwyczaj jeden & jeden lub kilka \\
\hline Przedmiot badań & $\begin{array}{l}\text { podstawowe pojedyncze zjawiska } \\
\text { ekonomiczne }\end{array}$ & $\begin{array}{l}\text { bardziej złożone zjawiska ekono- } \\
\text { miczne }\end{array}$ \\
\hline Zastosowane metody & $\begin{array}{l}\text { metody tradycyjne poznane w trak- } \\
\text { cie studiów i ich modyfikacje }\end{array}$ & $\begin{array}{l}\text { metody tradycyjne z elementami } \\
\text { własnych propozycji }\end{array}$ \\
\hline Dokonywane oceny & $\begin{array}{l}\text { ocena kształtowania się badanych } \\
\text { zjawisk ekonomicznych }\end{array}$ & $\begin{array}{l}\text { ocena współzależności różnch zja- } \\
\text { wisk ekonomicznych }\end{array}$ \\
\hline Formułowane wnioski & $\begin{array}{l}\text { wnioski dotyczące ustalonych pra- } \\
\text { widłowości o charakterze ex post }\end{array}$ & $\begin{array}{l}\text { wnioski dotyczące wykrytych pra- } \\
\text { widłowości i ich przyszłego przebiegu }\end{array}$ \\
\hline $\begin{array}{l}\text { Proporcje między częścią } \\
\text { teoretyczną i badawczą }\end{array}$ & $\begin{array}{l}\text { przewaga badań empirycznych nad } \\
\text { teorią }\end{array}$ & $\begin{array}{l}\text { zbliżona proporcja teorii i badań } \\
\text { empirycznych }\end{array}$ \\
\hline $\begin{array}{l}\text { Charakter ustalanych } \\
\text { prawidłowości }\end{array}$ & prawidłowości ogólne i strukturalne & $\begin{array}{l}\text { prawidłowości strukturalne i przy- } \\
\text { czynowo-skutkowe }\end{array}$ \\
\hline
\end{tabular}

Źródło: opracowano na podstawie: Bucior (2011); Kiziukiewicz (2013).

Z tabeli 2 wynika, że występują istotne różnice między badaniami empirycznymi przeprowadzanymi w ramach prac dyplomowych na różnym poziomie. Analizy empiryczne dokonywane w pracach magisterskich są bardziej zaawansowane niż w pracach licencjackich. Różnice te są spowodowane, przede wszystkim, różnymi oczekiwaniami co do umiejętności, jakie powinni posiąść studenci na porównywanych poziomach studiów ekonomicznych. Ważne jest to, że każda obligatoryjna praca dyplomowa z zakresu rachunkowości powinna zawierać część badawczą, która dotyczy konkretnej (wybranej) jednostki. Badania empiryczne 
w pełni realizują ten postulat i kształtują ważną umiejętność formułowania odpowiednich ocen i wniosków dotyczących prawidłowości kształtowania się analizowanych zjawisk ekonomicznych; dochodzi do tego jeszcze poznawanie realnie funkcjonujących jednostek i wybranego wycinka ich rzeczywistości (zjawisk i procesów gospodarczych).

Stopień zaawansowania technik wykorzystywanych w badaniach empirycznych, prowadzonych w ramach pracach licencjackich i magisterskich, nie jest jednakowy. W pracach licencjackich są to zazwyczaj klasyczne techniki analizy danych liczbowych poznane przez studentów w trakcie studiów w ramach różnych przedmiotów; często są to metody statystyki opisowej. W pracach magisterskich oczekuje się natomiast, aby oprócz metod poznanych przez seminarzystów w okresie studiów były dodatkowo zastosowane bardziej zaawansowane techniki badań empirycznych. Mogą to być np. metody ekonometryczne, taksonomiczne i badania operacyjne. Ponadto przyjęta metodyka badania empirycznego może być propozycją własną autora pracy magisterskiej (Bucior 2011).

\section{PODSUMOWANIE}

Rachunkowość stwarza podstawy do unifikacji badanych zjawisk, ponieważ ujmuje w jednostkach pieniężnych wszelkie zjawiska i procesy gospodarcze przebiegające w różnych jednostkach, bez względu na przedmiot ich działalności (Nowak 2007). Dzięki pomiarowi wartościowemu rachunkowość dostarcza zwięzłą informację ekonomiczną i stanowi podstawową bazę informacyjną dla biznesu. Informacje te uzyskuje się w rezultacie przetwarzania danych źródłowych dotyczących szczegółowych zdarzeń gospodarczych, zgodnie z obowiązującymi zasadami i procedurami. Ważne jest przy tym, aby informacje były dostosowane do potrzeb użytkowników, gdyż rachunkowość jest dyscypliną praktyczną.

Dane finansowo-księgowe, odzwierciedlające przebieg zjawisk i procesów gospodarczych, mają postać dostosowaną do specyficznych potrzeb ich użytkowników zewnętrznych i wewnętrznych. Często muszą być dodatkowo przetworzone w celu uczynienia ich bardziej czytelnymi i przydatnymi. Dopiero dane celowo przetworzone w procesie informacyjnym rachunkowości stają się informacjami ekonomicznymi (Curtis 1991).

Takie przetwarzanie danych empirycznych, dotyczących stanu zdarzeń gospodarczych ujmowanych w księgach rachunkowych oraz zjawisk ekonomicznych, prezentowanych w sprawozdaniach finansowych, powinno dotyczyć także prac dyplomowych z zakresu rachunkowości o charakterze badawczym. Chodzi bowiem o to, aby student potrafił dostosować tworzone informacje do potrzeb badania przeprowadzanego dla wybranej jednostki.

Podsumowując, należy stwierdzić, że przygotowanie przez studenta pracy licencjackiej lub magisterskiej z zakresu rachunkowości o charakterze teoretyczno-praktycznym jest ważnym elementem procesu dydaktycznego. Szczególną rolę odgrywają prace dyplomowe, które obejmują badania empiryczne przeprowadzone w wybranych jednostkach. Analiza danych empirycznych, pochodzących z konkretnej jednostki, jest bowiem najlepszym sposobem na poznanie określonego wycinka działalności. Ważne jest, aby na podstawie przeprowadzonego badania empirycznego student potrafił sformułować odpowiednie oceny i wnioski nie tylko o charakterze ex post, ale także ex ante. Jest to niezbędny element każdej pracy obligatoryjnej realizowanej na studiach ekonomicznych, w tym zwłaszcza na studiach z zakresu rachunkowości. 


\section{PIŚMIENNICTWO}

Bucior G. 2011. Wymagania dotyczące prac magisterskich w Katedrze Rachunkowości Uniwersytetu Gdańskiego. Folia Pomer. Univ. Technol. Stetin., Oeconomia 287(63), 23-30.

Curtis G. 1991. Business information system. analysis, design and practice. New York, Addison-Wesley Publishing Company, 3-4.

Hendriksen E.A., Breda M.F. van. 2002. Teoria rachunkowości. Warszawa, Wydaw. Nauk. PWN, 35-36.

Kiziukiewicz T. 2012. Systematyzacja wymagań wobec prac akademickich. Folia Pomer. Univ. Technol. Stetin., Oeconomica 294(67), 107-116.

Nadolna B. 2009. Metodologiczne aspekty prac naukowych z zakresu nauk ekonomicznych. Folia Pomer. Univ. Technol. Stetin., Oeconomica 273(56), 149-154.

Nowak E. 2001. Analiza statystyczna w ocenie działalności przedsiębiorstwa, w: Metody statystyczne w analizie działalności przedsiębiorstwa. Red. E. Nowak. Warszawa, PWE, 11-18.

Nowak E. 2016. Analiza kosztów w ocenie działalności przedsiębiorstwa. Warszawa, CeDeWu, 26-29.

Nowak M. 2007. Rachunkowość, controlling, zarządzanie. Rozważania o relacjach, w: Paradygmaty rachunkowości. Red. E. Nowak. Wrocław, Wydaw. AE, 58-73.

Suchecka J. 2011. Wybór adekwatnych technik ilościowej analizy, w: Zasady przygotowania pracy badawczej przez doktorantów. Red. K. Safin. Wrocław, UE, 50-91. 
